\title{
Impression Management Tactics Employed by Primary school Heads to Influence Management and Leadership Decisions in Schools: A Survey of Two Districts in Zimbabwe
}

\author{
Shepherd Shoko, PhD \\ Midlands State University, Zimbabwe \\ Wonderful Dzimiri, PhD \\ Midlands State University, Zimbabwe
}

\begin{abstract}
Of late, there has been increased research interest in impression management tactics in employment interviews. This study took a detour and investigated impression management tactics used by primary school heads to influence management and leadership decisions in their schools. Underpinned by a mixed methods paradigm, a descriptive survey research design was used wherein fifty selected school heads from two districts in Zimbabwe participated in the study. The school heads responded to a questionnaire and interviews. Data revealed that school heads used self promotion, Association, ingratiation, exemplification, supplication, and intimidation tactics in rank order respectively, to build impressions around their leadership capabilities. A major conclusion was that, these impression management tactics are used differently in different organisation types. It was recommended that the study of impression management in educational leadership and management, which is currently receiving peripheral attention, should be foregrounded to enhance the practice of leadership and management in education.
\end{abstract}

Keywords: Impression Management, Leadership, Ingratiation, Exemplification, Intimidation, Supplication, Association.

\section{INTRODUCTION}

The study investigated impression management tactics school heads use to manage evaluations teachers make of their management and leadership abilities. Personal observation from practice is that management and leadership success is hinged on how those who are led perceive the leader's potential to lead through an evaluation of the leader's leadership behaviours and actions. One way to understand these leadership behaviours and action is by seeing leaders as actors on a 'social stage' who are actively trying to sell to their audience a particular image of themselves and what they stand for. Consciously or unconsciously, our realisation was that school heads invest a lot of their leadership and management time trying to manage the impressions teachers and other stakeholders form about them and the schools they lead (i.e. branding their management and leadership, and also the schools they lead). However, of late the area of impression management has not received attention in educational leadership and management discourse in Zimbabwe and, indeed, many other countries (Rosenfield, Giacalone \& Kennedy, 1987). Impressions that teachers and other stakeholders have for the leader and the school that one leads have a bearing on the success or failure of the leader's efforts to run the school well. Since this article draws heavily on the concept of impression management, unpacking of the concept and its use in the article becomes pertinent. 


\section{REVIEW OF RELATED LITERATURE}

It is not a new idea that people engage in calculated behaviours to control the impressions that those observing them form (Rosenfield, \& Giacalone, 1987). Most people, particularly leaders, are concerned with making good first impressions on others about themselves or the organisations they are leading. Influencing perceptions through positive impressions is the hallmark of the art of leading. Making good first impressions is the subject of Impression management (Ashraf, 2013). A more elaborate definition of impression management is given by Singh (2013) who sees impression management as a goal-directed, conscious or unconscious attempt to influence the perceptions of other people about a person, object or event by regulating and controlling information in social interaction. The sociologist Erving Goffman was mainly responsible for the formulation of Impression management theory. Goffman argues that the self is simply nothing more than 'Self Presentations' and 'Role Performances' aimed at influencing the observers (Goffman, 1959). Goffman's theory states that any individual (leader) or organization must establish and maintain impressions that are in agreement with the perceptions they want to convey to the target group. The goal of managing impressions is for the individual or organisation managing the impressions to present themselves in a way that they would like to be thought of by significant others constituting the audience. Impression management tactics are many but they basically fall into two broad categories viz: self-enhancement where the agent makes an effort to increase their appeal to others, and other-enhancement where the agent tries to make the target person feel good in various ways so as to influence the target person to form positive impressions about the agent (Goffman, 1959).

Impression management has gained a lot of attention in research circles of late. For example, Deepak (2014) claims that, at work, doing a good job accounts for $10 \%$ of the impression you give and $90 \%$ of the impression you give of being capable is based on perception presentation of work - presentation of self - being seen to be 'doing a good job. If this is anything to go by, it follows then that the concept of impression management is not something any person, particularly a school head, can afford to ignore, especially those who have a concern to 'brand' their leadership and schools.

If the impressions that leaders of organisations form have a lasting effect on perceptions of the led and the confidence they can have in the leader's leadership, it can be argued that the reality of successful leadership is, to a large extent, a function of perception. Therefore, it is imperative for school heads leading and managing school organizations to be conversant with the basic elements or behaviours involved in generating positive perceptions about impressions they send out to their subordinates at any given time (Gwal, 2015).This creates in followers the right perceptions that augur well with the leader's envisaged organisational goals.

Impression management can also be seen as a form of leadership behaviour. This can be inferred from Botha's (2013) and Yukl's (2010) definitions of leadership. They see leadership as the process of influencing opinions that followers form about the organisation and its goals. However, the ability to lead or to influence lies, foremost, with the ability of the leader to evoke in followers certain impressions about the one's leadership that followers find attractive (impression management). It is also argued that we engage in impression management in order to be influential (Schlenker and Pontari, 2000). Therefore, for leaders to be effective in influencing followers, they must put up a front (impression management) in order to 'sell' a particular image of themselves and the organisation they lead, and that they believe followers and stakeholders would find acceptable. In school organisations, school heads may engage in impression management in order to conform to situational norms, for identity development, and for social approval. In addition, impression management strategies have a lot to do with 
the protection and maintenance of power, and have an impact on the school's culture and performance (Jones \& Pittman, 1982). Arguably, the leader's potential to influence school culture and exercise power and leadership in the school is hinged on the leader's ability to manage impressions he or she sends out to followers about his or her leadership. Arguably, in this context, impression management becomes the golden thread that ties effective organisational leadership and management together.

Research on impression management has been robust in areas such as assessment and job interviews (Peeters \& Lievens, 1986), business ethics (Giacalone \& Payne, 1987), and personal space invasions (Rosenfield, Giacalone \& Kennedy, 1987). Of late, organisational literature on impression management has been trickling in. For example, Robbins (2005), and recently Gwal (2015) and Robins and Judge (2015) have written about impression management in business organisations. In the context of business organisations, these researchers focused mainly on impression management from a sociological perspective, and where their research focused on the school organisation, only a cursory treatment is given (Rosenfield, \& Giacalone, 1989). A rare attempt, however, was done by Gwal (2015) who investigated impression management tactics used by Academicians, Doctorates and Post Graduate employees to influence employer perceptions at a university. As a result, despite its strong appeal and importance for organisational leadership and management in school organisations as already alluded to, not much research literature has been dedicated to this area of late. This study aims to pug this important void by looking at impression management tactics in education, particularly looking at primary school heads. Closely following Gwal (2015)'s methodology, though using a different target group and a slightly bigger number of impression management tactics than those used by Gwal, we investigated how fifty school heads in Gwanda district of Matebeleland South province and Zvishavane district in the Midlands province in Zimbabwe use impression management tactics to influence teachers about their leadership from an educationist perspective. This is very important since such knowledge can go a long way in improving leadership effectiveness in schools, as well as informing leadership preparation programmes in education. The study further adds to the existing body of knowledge by providing evidence that is Zimbabwe-specific.

This study sought to:

\section{OBJECTIVES OF STUDY}

1. Determine impression management tactics school heads use to sell their management an d leadership images to teachers.

2. Identify particular behaviours that all school heads often engage in for impression man agement and those they engage in the least.

\section{RESEARCH METHODOLOGY}

This study is couched in the mixed methods paradigm wherein both quantitative and qualitative approaches were adopted within the descriptive research design. Descriptive research is a type of enquiry that aims to describe important factors associated with a situation, such as events, behaviours, attitudes, experiences, and knowledge (Kelley, Clark, Brown \& Sitzia, 2003; Hale, 2011). Hale (2011) says with the descriptive design, one can choose from three main types of descriptive methods: observational methods, case-study methods and survey methods. Hale (op. cit.) further says that in survey method, research participants answer questions administered through interviews or questionnaires. This study made use of the descriptive survey method and made use of a questionnaire and interviews to gather data to describe impression management behaviours of primary school heads in two provinces of Zimbabwe. Impression management tactics school heads use against teachers were measured by a scale adapted from Bolino and Turnley (1999), based on the classification 
system proposed by Jones and Pittman (1982). A total of 50 school heads randomly selected in Gwanda district of Matebeleland South province and Zvishavane district in the Midlands province in Zimbabwe participated in the study, with 10 of them responding also to interviews. To answer the questionnaire, school heads were asked to think about how often they behave in ways described in statements in the questionnaire in their interaction with teachers. Possible responses were never, often, and always. The questionnaire consisted of four sets of statements based on the following impression management tactics, of which the first five were identified by Jones and Pittman (1982), and the sixth one described by Madhubhashini (2014). Self-Promotion is whereby individuals point out their abilities or accomplishments in order to be seen as competent by observers; Ingratiation, whereby individuals do favours or use flattery to elicit an attribution of likability from observers; Exemplification, whereby people self-sacrifice or go above and beyond the call of duty in order to gain the attribution of dedication from observers; Intimidation, where people signal their power or potential to punish in order to be seen as dangerous by observers; and Supplication, where individuals advertise their weaknesses or shortcomings in order to elicit an attribution of being needy from observers (Gwal, 2015). Association is whereby individuals enhance or protect their image by managing information about people and things that they associate with. The statements about these impression management tactics were slightly adapted to this study and were not written following the order in the original questionnaire to avoid tipping respondents about which particular tactics they will be responding to at any point in time. The order that appears in the table below is only meant to aid analysis. Interviews were carried out with ten school heads randomly selected after initial analysis of data from the questionnaire. The objective was to get elaborations on school heads' responses to the questionnaire.

Ethical issues involve drawing up a set of principles to protect the rights of participants in research (McMillan and Schumacher, 2014). In line with this, we avoided use of participants' names to protect the identity of participants and schools. School heads were given all relevant information before they opted to participate, and were free to terminate their participation at any given time. All data gathered were kept in confidence and permission to carry out the study was sought before carrying out the study.

Quantitative data were analysed using SSPS software whereby simple descriptive statistics were used in the analysis. Our choice of using Bolino and Turnley (1999)'s standardised instrument and a large sample of school heads from two different provinces of the country was a way of trying to enhance the reliability of findings of this study. Interview data were analysed thematically guided by the tactics presented in the questionnaire, and thus were fused in the analysis. In the sections that follow, we present and discuss data from the questionnaire and fuse in interview responses in the analysis.

\section{RESULTS AND DISCUSSION}

Table 1 below presents data from questionnaires distributed to 50 school heads. The table was adopted from Bolino and Turnley (1999) with minimal modification to fit school contexts. In the table, statements about each impression management tactic were grouped together for ease of analysis. The score of each statement out of fifty was given to demonstrate its relative popularity with school heads when compared with scores measuring the same construct. The average column shows the popularity of the tactics measuring each construct on average. To get the construct mean, item means measuring the popularity of use of each tactic statement when compared with the twenty four statements in the questionnaire were averaged. 
Table 1: Summary of data from questionnaires

\begin{tabular}{|c|c|c|c|c|c|c|}
\hline STATEMENTS & 芯 & 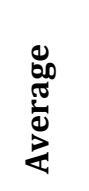 & 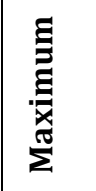 & $\stackrel{\Xi}{\Xi}$ & 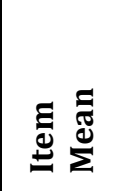 & 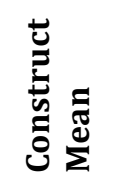 \\
\hline \multicolumn{7}{|l|}{ Self-promotion } \\
\hline $\begin{array}{l}\text { Talk proudly about your experience or } \\
\text { education. }\end{array}$ & 39 & \multirow{4}{*}{41} & \multirow{4}{*}{44} & \multirow{4}{*}{37} & 0.78 & \multirow{4}{*}{0.81} \\
\hline $\begin{array}{l}\text { Make teachers aware of your talents or } \\
\text { qualifications. }\end{array}$ & 37 & & & & 0.74 & \\
\hline $\begin{array}{l}\text { Let teachers know that you are valuable to the } \\
\text { organization. }\end{array}$ & 44 & & & & 0.88 & \\
\hline $\begin{array}{l}\text { Make teachers aware of your accomplishments at this } \\
\text { and other schools you worked at in the past. }\end{array}$ & 42 & & & & 0.84 & \\
\hline \multicolumn{7}{|l|}{ Ingratiation } \\
\hline $\begin{array}{l}\text { Compliment your teachers so they will see you } \\
\text { as likable. }\end{array}$ & 35 & \multirow{4}{*}{28} & \multirow{4}{*}{35} & \multirow{4}{*}{14} & 0.70 & \multirow{4}{*}{0.55} \\
\hline $\begin{array}{l}\text { Take an interest in your teachers' personal lives } \\
\text { to show them that you are friendly. }\end{array}$ & 26 & & & & 0.52 & \\
\hline $\begin{array}{l}\text { Praise your teachers for their accomplishments } \\
\text { so they will consider you a nice person. }\end{array}$ & 35 & & & & 0.70 & \\
\hline $\begin{array}{l}\text { Do personal favours for your teachers to show them } \\
\text { that you are friendly. }\end{array}$ & 14 & & & & 0.28 & \\
\hline \multicolumn{7}{|l|}{ Exemplification } \\
\hline $\begin{array}{l}\text { Stay at work late so teachers will know you are } \\
\text { hard working. }\end{array}$ & 29 & \multirow{4}{*}{27} & \multirow{4}{*}{47} & \multirow{4}{*}{11} & 0.58 & \multirow{4}{*}{0.545} \\
\hline $\begin{array}{l}\text { Try to appear busy, even at times when things } \\
\text { are slower. }\end{array}$ & 22 & & & & 0.44 & \\
\hline Arrive at work early to look dedicated & 47 & & & & 0.94 & \\
\hline $\begin{array}{l}\text { Come to the office at night or on weekends to } \\
\text { show that you are dedicated. }\end{array}$ & 11 & & & & 0.22 & \\
\hline \multicolumn{7}{|l|}{ Intimidation } \\
\hline $\begin{array}{l}\text { Be intimidating to teachers when it will help } \\
\text { you get your job done. }\end{array}$ & 16 & \multirow{4}{*}{22} & \multirow{4}{*}{29} & \multirow{4}{*}{16} & 0.32 & \multirow{4}{*}{0.44} \\
\hline $\begin{array}{l}\text { Let teachers know you can make things } \\
\text { difficult for them if they push you too far. }\end{array}$ & 25 & & & & 0.50 & \\
\hline $\begin{array}{l}\text { Deal forcefully with teachers when they hamper } \\
\text { your ability to get your job done. }\end{array}$ & 29 & & & & 0.58 & \\
\hline $\begin{array}{l}\text { Deal strongly or aggressively with teachers who } \\
\text { interfere in your business. }\end{array}$ & 18 & & & & 0.36 & \\
\hline \multicolumn{7}{|l|}{ Supplication } \\
\hline $\begin{array}{l}\text { Act like you know less than you do so teachers } \\
\text { will help you out. }\end{array}$ & 22 & \multirow{4}{*}{23} & \multirow{4}{*}{29} & \multirow{4}{*}{18} & 0.44 & \multirow{4}{*}{0.46} \\
\hline $\begin{array}{l}\text { Try to gain assistance or sympathy from } \\
\text { teachers by appearing needy in some areas. }\end{array}$ & 23 & & & & 0.46 & \\
\hline $\begin{array}{l}\text { Pretend not to understand something to gain a } \\
\text { teachers' help. }\end{array}$ & 18 & & & & 0.36 & \\
\hline $\begin{array}{l}\text { Act like you need assistance so teachers will } \\
\text { help you out. }\end{array}$ & 29 & & & & 0.58 & \\
\hline \multicolumn{7}{|l|}{ Association } \\
\hline $\begin{array}{l}\text { Associate more with teachers doing well in their } \\
\text { work in the school }\end{array}$ & 37 & \multirow{4}{*}{30} & \multirow{4}{*}{37} & \multirow{4}{*}{21} & 0.74 & \multirow{4}{*}{0.59} \\
\hline $\begin{array}{l}\text { Control information teachers know about your } \\
\text { friends, relations and places you frequent. }\end{array}$ & 21 & & & & 0.42 & \\
\hline $\begin{array}{l}\text { Relate with influential people or high figures so } \\
\text { that teachers can associate you with } \\
\text { achievements of these people. }\end{array}$ & 25 & & & & 0.50 & \\
\hline $\begin{array}{l}\text { When your school loses in games, avoid talking } \\
\text { much about it. }\end{array}$ & 35 & & & & 0.70 & \\
\hline
\end{tabular}


The column graph below was derived from the table above to aid analysis of the data presented in the table above. A discussion of the findings was then done with the aim of gaining some insights about school heads' use of impression management tactics.

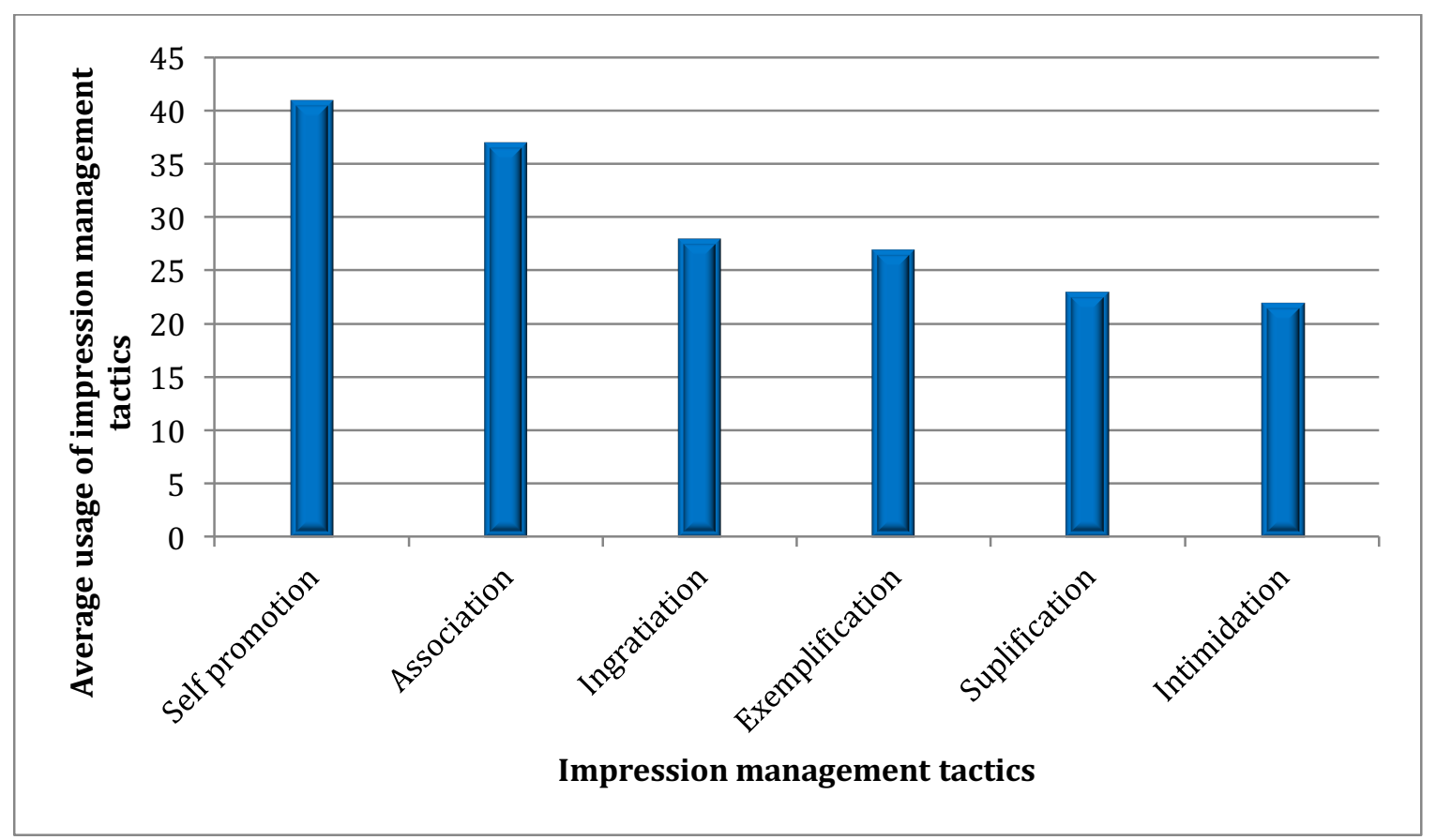

Figure 1: School heads' use of impression management tactics

In the next section we analyse data about each impression management tactic.

\section{Self-promotion}

As shown in the graph, the majority of school heads used self-promotion to manage impressions they send out to teachers about their leadership and management. The most popular statement school heads used to self-promote was, 'Let teachers know that you are valuable to the organization,' which had a score of 44 out of 50 . In the same category, the statement 'Talk proudly about your experience or education' was least used by the majority of school heads with a score of 39 out of 50 . However a score of 39 out of 50, though ranked least against others, still suggests high usage of the tactic in general. Gwal (2015, p. 41) says, "Selfpromotion is a proactive process in which the self-promoter has to actively say things to show the competence or at least undertake actions so that the competence is displayed to the target." Evidence from interviews revealed that school heads displayed their competences by displaying charts in their offices showing all teachers' academic qualifications. They came first on the charts and them with the highest qualification and teaching experience in most cases. Commenting on this, one school head said, "With the qualifications you see on that chart over there, who can doubt my leadership?" They also displayed good grade seven terminal results on charts in their offices for all to see how good their instructional leadership was. Most of the school heads had a tendency of using self descriptive communication to be seen as competent and that their contributions to the school were very valuable. The school heads were very generous when it came to sharing with teachers and also the researcher, their successes and critical contributions they made to programmes and projects that they implemented in their schools. During interview sessions, seven out of ten school heads wanted us to tour their schools and see for ourselves some of the achievements attributed to them during their tenure of office at their current schools. The school heads showed a lot of confidence, something that we thought was a good thing for bolstering teachers' and, indeed, anyone else's perceptions about their abilities to lead. 


\section{Association}

It emerged that after self-promotion, association was the most popular impression management tactic with a construct mean of 0.59 . Most school heads preferred the tactic, 'associate more with teachers doing well in their work in the schools.' However statistics show that the tactic 'Control information teachers know about your friends, relations and places you frequent' was least preferred with a score of 21 out of 50. Preferring to associate more with teachers doing well in their work in the schools may be seen as a way of trying to maintain impressions that are congruent with perceptions they want to convey to their teachers and the general public; that of being associated high standards and success. This may also have been a way of building and nurturing a culture of hard work in the schools. Association behaviours may also be a way of projecting an 'idealised image' or social identity of a successful school, downplaying any challenges. For example, most school heads interviewed echoed one school heads's views on this issue who said, "If you as school head are seen to be well connected with high profile figures, you end up being seen like one and your school 'chinopika malevels' [ your school earns a dignified and reputable image and status]." This was very important for teachers and parents of the schools for it had the potential to raise their self efficacy levels which may contribute to improved performance. This was seen as enhancing members' organisational citizenship behaviours. Hobman, Jackson, Jimmieson and Martin (2011) define organisational citizenship behaviours as voluntary loyalty and commitment to the leader, willingness to cooperate with the leader, enhanced motivation to contribute to the group, and members' desire to identify with the group and the organisation the leader is leading. If choosing one's associations well may invigorate such positive feelings and attitudes in followers, then school heads who wish to be effective leaders should strive to manage impressions they may send out to teachers as a result of their associations.

\section{Ingratiation}

The ingratiation tactic of impression management was found to be the third most popular tactic. Data shows that the most popular statements school heads used to influencing the teachers' liking for their leadership behaviours were, 'Compliment your teachers so they will see you as likable' and 'Praise your teachers for their accomplishments so they will consider you a nice person, which were tied at a score of 35 out of 50.' Probably, due to negative connotations associated with currying for favours the tactic, 'Do personal favours for your teachers to show them that you are friendly' was the least preferred with a score of 14 out of 50. Evide nce from interviews revealed that, as a way of praising teachers so as to portray a good image of the self, the majority of school heads said they thanked teachers after important ceremonies such as the Prize giving day, Parents day, and also after winning at sports and other tournaments. This positive recognition of teachers' efforts by school heads evoked positive feelings towards the heads as was seen by teachers' spirited commitment to such activities whenever they occurred in the school. From these data, it can be said that these positive compliments by school heads were used to form a class of strategic behaviours illicitly designed to influence teachers concerning the attractiveness of school heads' personal qualities. The goal of ingratiation tactics by school heads was to be likeable by teachers whose evaluation of their leadership was deemed critical for their leadership success. Being likeable by teachers is important for leadership because research literature has shown that followers like, and can easily be influenced by leaders who think or act like them and with whom they share the same values and beliefs (Mallya, Murthy \& Mirza, 2010; Signh, 2013; Gwal, 2015). It may be important to note that, whilst Ingratiation was found to be the most popular tactic when used by subordinates in Gwal (2015)'s study, findings of this study (using leaders) found it to be a third runners up to Self-promotion and Association with construct means of 0.81 and 0.59 respectively, versus the 0.55 for Ingratiation. This may suggest that the impression 
management of Association, which was not part of Gwal (2015)'s study and was investigated in this study is a very popular tactic with school heads.

\section{Exemplification}

Based on the results of this study, exemplification came fourth as the most used impression management tactic with a construct mean of 0.545 . However, this tactic had almost the same construct mean as ingratiation with a construct mean of 0.55 . The popularity of this tactic was boosted by the exemplifier item, 'Arrive at work early to look dedicated' which had the biggest score of 47. However this study could not separate this behaviour from the dictate of policy, which requires teaching staff to clock in the school head's office, who must be in the office 15 minutes before starting time. This assertion is further strengthened by respondents' unwillingness to sacrifice their time off and spare time because the tactic, 'Come to the office at night or on weekends to show that you are dedicated' received the least score of 11 out of 50. According to Gwal (2015, p. 42), exemplification influences target persons' behaviours by, "...attempting to make others feel guilty because they are not acting in a same morally and integer manner." By implication, to reduce their feelings of guilt, teachers would usually support the cause of the school head. Whilst this tactic is relatively popular with school heads, it may be the least popular with teachers as inferred from Gwal (2015)'s study where lower level employees preferred to use this tactic against their bosses the least.

\section{Supplication}

To a lesser extent, school heads used Supplication, which had a construct mean of 0.46. However when they used it they preferred to use the tactic, 'Act like you need assistance so teachers will help you out,' which had a score of 29 out of 50. The school heads emphasized their own dependence and weakness to obtain help from teachers who, in this case, seemed to have significant influence over leadership and management outcomes. The majority of school heads interviewed said this tactic was most effective if used in conjunction with stories from the bible. Among others, the parable of the unmerciful servant from the Bible was mentioned by six out of ten of the school heads interviewed as a favourite when they wanted to trigger attributions of being needy. We asked ourselves why school heads who are believed to be assertive people may want to influence by displaying their weaknesses. We concluded that such school heads used this tactic after having been unable to use successfully the assertive behaviours presented previously, and thus resort to exploiting their own weaknesses. Arguably, this tactic may yield positive results particularly if used with more powerful others like donors and powerful local leaders, very senior and influential teachers and politicians. By advertising their lack of ability to these powerful individuals, the school heads may be attempting to activate a powerful social rule, the norm of social responsibility that says you should help those who are in need (Rosenfeld, Giacalone, \& Riordan , 1995). However, "One heavy cost attached to using supplication is the costs of one's self-esteem in admitting one's incompetence," (Gwal, 2015, p. 42). Findings in this study confirm this assertion by Gwal (2015). This is because, whilst school heads could risk showing teachers they could not go it alone all the time, they were not at ease showing their incompetence, hence a least score for the tactic, 'Pretend not to understand something to gain a teachers' help'.

\section{Intimidation}

Intimidation was the least used impression management tactic of all, with a construct mean of only 0.44 . The most common statement chosen by the school heads was, 'Deal forcefully with teachers when they hamper your ability to get your job done,' which had a score of 29 out of 50. Whilst this tactic enjoyed some popularity when used by employees against their bosses in Gwal (2015)'s study, in this study it was at the bottom of the list of supervisors (school heads)'s list. Unlike teachers, this may suggest that school heads use this tactic less frequently. 
In interviews, Zimbabwe Statutory Instrument 1 of 2000, which presents a schedule of Acts of Misconduct for civil servants, was the most popular intimidatory tool used by school heads to validate their threats to teachers. Most school heads shared the view that, as school head, one did not have to show subordinates that he/she was powerless. This is summed up on sentiments by one female school head who said, "You can't be an effective head if you demonstrate to your teachers that you are powerless all the time." By being the least used impression management tactic, results of this study may be suggesting that if soft impression management tactics were not working, school heads became intimidators who care less about being likeable, resorting to control and exerting their legitimate power over teachers as a last resort. However, they did not like a label of being seen as being ever intimidating bosses, hence a least score for the tactic, 'Be intimidating to teachers when it will help you get your job done' which had a score of only 16 out of 50 .

\section{CONCLUSION}

The study has revealed that impression management, apart from being very popular in employment interviews and private sector organisations, it is also applicable in educational organisations. The popularity of use of the impression management tactics investigated in this study can be rank ordered this way; Self-promotion, Association, Ingratiation, Exemplification, Supplication and Intimidation. The differences in rate of use of the impression management revealed by different studies cited herein may be an indication that school heads and teachers employ impression management tactics differently. Furthermore, it may also suggest that different organisation systems use the impression management tactics differently.

\section{RECOMMENDATIONS}

i) It is recommended that school heads should seriously consider the use of various im pression management tactics as a way of putting a favourable front about their leade rship and management.

ii) Whilst this study looked at the use of impression management tactics as being used i ndividually, in reality these tactics may not be standing in silos. The probability of th em being used in certain combinations for more effective outcomes is high and it is $r$ ecommended that further research looking at different combinations of use be done in future.

iii) The study of impression management in leadership and management, which is curre ntly receiving peripheral attention should be foregrounded to enhance the practice $o$ f leadership and management in education.

\section{References}

Ashraf, J. (2013). Impression management. Accessed 20 September 2017 on

https://www.slideshare.net/junaidchohan/impression-management-28648923?next_slideshow=5.

Bolino, M. C., \& Turnley, W. H. (1999). Measuring Impression Management in Organizations: A Scale Development Based on the Jones and Pittman Taxonomy. Organizational Research Methods, 2(2), 187.

Botha, R. (2013). Epistemological beliefs and leadership approaches among South African school principals. Educational Studies, 39(4), 431-443.

Deepak, I. S. S. (2014).Impression management Techniques and

Tacticshttps://www.slideshare.net/529912/impression-management-techniques-and-tactics?next_slideshow=1

Gwal, R. (2015). Tactics of Impression Management: Relative Success on Workplace Relationship. The International Journal of Indian Psychology, (2) 2, B00362V2I22015.

Giacalone, R. A., \& Payne, S. L. (1987). Is business staging a morality play? Business and society review. 31-35.

Giacalone, R. A., \& Rosenfield, P. (Eds.) (1989). Impression management in the organisation. Lawrence Erlbaum associates publishers: New Jersey. 
Goffman E. (1959). The presentation of self in everyday life. Garden City: New York.

Hale, J. (2011). The 3 Basic Types of Descriptive Research Methods. Accessed September 14, 2017, from https://psychcentral.com/blog/archives/2011/09/27/the-3-basic-types-of-descriptive-research-methods/

Jones, E. E., \& Pittman, T. S. (ed.), (1982). Toward a General Theory of Strategic Self- presentation: Psychological perspectives on the Self, Journal Suls, 1: 231-262.

Kelley, K., Clark, B., Brown, V., \& Sitzia, J. (2003). Good practice in the conduct and reporting of survey research, International Journal for Quality in Health Care, Volume 15, Issue 3, 1 May 2003, Pages 261-266, Accessed August 15, 2017 from https://doi.org/10.1093/intqhc/mzg031

Madhubhashini, D. (2014). Impression Management. Retrieved on August 82017 from https://www.slideshare.net/dkdmadhubhashini/impression-management-38628289?next_slideshow=4

Mallya, V., Murthy, N., \& Mirza, S. (2010). Impression management perception of self- image and behaviour. LinkedIn Corporation (C) 2017

McMillan, J. H., \& Schumacher, S. (2014). Research in education: Evidence-based inquiry: Boston: Pearson Higher Ed.

Peeters, H., \& Lievens, F. (1986). Verbal and Nonverbal Impression Management

Tactics in Behavior Description and Situational Interviews. International Journal of Selection and Assessment, 14 (3), 206-222.

Robbins, S. T. (2005). Organisational behaviour. Prentice Hall Pvt (Ltd): New Dehli

Robbins, S. T. \& Judge, T. A. (2015). Organisational behaviour. Pearson: Boston

Rosenfeld, Giacalone, \& Riordan. (1995). Impression Management in Organizations: Theory, measurement, practice: Routledge, London.

Rosenfield, P,. Giacalone, R. A., \& Kennedy, J. G. (1987). Of status and suits: Personal space invasions in administrative settings. Social Behaviour and Personality, 15, 93-95.

Schlenker, B. R., \& Pontari, B. A. (2000). The strategic control of information: Impression management and selfpresentation in daily life. In A. Tesser, R. Felson, \& J. Suls (Eds.), Perspectives on Self and Identity (pp. 199-232). Washington, DC: American Psychological Association.

Singh, V. Y. (2013). Impression management. Accessed 01 September 2017 on https://www.slideshare.net/yash231192/impression-management-25885236.

Yukl, G. (2010). Leadership in Organizations. Upper Saddle River, NJ: Pearson: Prentice Hall. 